\title{
Inter-Relationship between Women and Nature: A Critical Study of the Fictions of Anita Desai
}

\author{
Dr. Tejaswini Behera \\ Lecturer in English \\ Bhuban Women's Higher Secondary School \\ Bhuban, Dhenkanal, Odisha, India \\ tejaswinibehera11@gmail.com
}

\begin{abstract}
The inward or inner agony, pressure and any other issues of women life are reflected in a peculiar way through the Nature or its natural objects of as we can clearly point out in the novels of Anita Desai. The female protagonists of the novels of Anita Desai could not express their inner feelings before their male partners or anybody as they express themselves properly and smoothly through Nature and its different Natural objects. In other words, we can say that life of the women protagonists in the novels of Anita Desai and Nature are closely connected with each other. As Nature and women both have the power of nurturing and sustenance, which means both of them carry maximum similar feminine qualities. So to maintain peace and equality in the society, we should have to understand the inward feelings of both women and Nature.
\end{abstract}

Keyword: Nature, Woman, Feminism, Emotion, Feelings

Introduction

The leading women characters in the fictions of Anita Desai express their feelings very beautifully through Nature. So Nature plays as a source of hope and happiness for the women protagonists, who live an inward barren life. Nature provides the soul to her novels 
through which a proper form and style is created. The flowers, grass, mountains, animals and birds are the Natural objects through which the female protagonists express their inward pain in a lively manner. The women characters are emotionally psychologically breakdown for which they could not express their feelings properly with the outer world try to squeeze themselves inwardly. So they properly express their emotions through these Natural objects. Everywhere in the fictions of Desai, we find the natural objects as an intimate fellow-being and her friend of her female protagonists.

In the first novel Cry the Peacock of Anita Desai, we can notice, the way through which Nature and natural objects help and prompt the protagonist Maya to express her inward feelings properly. She merges her pain with the flowers as she smells their fragrance: "I bent upon them, inhaling that mist of sad maidenly scent feeling, mood merge into mood, sensation into sensation, till there was nothing left but that mist."(21) The Spring season reminds her of her childhood. She considers her childhood garden where she took the breakfast with her father was a land of fantasy. Maya recalls: "Our table is laid beside a mandarin orange tree, there is one in each corner of the garden a little faery tree, with its glossy leaves and an overload of small, bright miniature lanterns on a carnival night." (44) Maya's garden of childhood and the garden of her present life are completely opposite to each other. While she finds the garden of her father and neighbour as a protected one, her own little garden looks very neglected to her for which she feels very lonely and deserted due to the behave of her middle aged and deserted husband. She says, "I have failed to care for my garden for so long now, and the gardener has neglected it." (180) In Maya's paradisiac garden, the astrologer enters in the disguise of a snake. "Overcome by a sensation of snakes coiling and uncoiling their moist length about me, of evil descending from an over-hanging branch of an insane death, unprepared for heralded by deafening drum beats." (13) The natural images like the birds, animals, flowers, mountains and gardens provide the inner 
solace to face the bitter reality of life. Sudden demise of Toto instincts him to believe in the Albino Aestrologer's words, which is there in her subconscious mind. Her insatiable desire for mating is reflected and expressed through the nesting birds: "On our verandah, the pigeon's nests were suddenly filled with babies that twittered, muttered and whispered and whimpered all day..." (34) Maya's internal desire and frustration is reflected through the natural image, the Peacock. The outward natural storm reflects the inward pain and depression of Maya quite clearly. The mating cry of the peacock reminds Maya's feeling of loneliness and death. "Pia-Pia-Lover, Lover, Mio, mio- I die...Living, they are aware of death. Dying they are in love with life." (95-96). This natural image inject in Maya's lunatic mind in the Summer season during fourth and decisive year of her marriage to take a drastic decision of death, which is of Gautama's as he was completely detached from love and emotion and forget all his responsibilities towards Maya.

In Where Shall We Go This Summer? , sea, water, fish, eagle and crow are the natural images through which the female protagonist Sita expresses her inner desire and pain. Sita feels very happy and never feels lonely in Nature: "She never felt alone. She felt surrounded by presences- the presence of the island itself, of the sea around it and of the palm trees alive." (126) She feels like a jelly fish who is standing on the coast of a sea and feels, "Perhaps I am only the jelly fish washed up by the waves, stranded there on the sand bar. I was just stranded here by the sea, that's all." (152) The episode of eagle-crow fighting restricts her not to give birth her fifth child in a city of violence and insecurity and also snatches the moral values of her children as all the time, they are also fighting with each other.

In Clear Light of Day, we see that the female protagonist Tara finds the garden of her childhood in a neglected condition. Between two beds of roses we see a strip of grass at the end of the garden, where Tara took a walk with her mother in her childhood and screaming at 
the sight of a snail. Now, at this young stage of life, she plays with the snails and recalls her protected childhood days looking at which Bim in surprised. She not only sees their garden in a neglected condition but also finds the garden of neighbours in the same unprotected condition, where she naturalizes to find the peace, protection and refreshment of her childhood.

Fire on the Mountain shows us how the protagonist, Nanda Kaul, wife of a ViceChancellor leaves back the disturbed, hectic and neglected life and decides to move to the Carignano hills for peace and privacy. The needs of her neglected and painful soul is fulfilled here at last in this calm and silence atmosphere of the hills. "It was the place and the time of life that she had wanted and prepared for all her life as she realized on her first day at Carignano, with a great, cool-flowering of relief and at last she had it. She wanted no one and nothing else." (3) The garden of Carignano gives solace and peace and provides her the privacy which her agonized soul craves all through her life. She does not like to plant any tree in the garden as its previous owners and likes the bare and empty places inside it as she connects her past life with it quite easily. "No she reveled in its bareness and emptiness. The loose pebbles of the garden pleased her as much as rich turf night another. She cared not to add another tree to the group of apricots by the verandas or the group of three pines at the gate. (31) When, her grand-daughter, Raka, comes to live with her though she does not like the interference of any of her family members to disturb her peace, but after few days looking at the silent and calm attitude carrying while she disappears in the hills and forests of Carignano without informing or disturbing anybody, her mentality completely changed towards her grand-daughter. Looking at the love and attachment of Raka with the place, she heartily accepts that "Certainly it belonged to no one else, had no meaning for anyone else. Raka alone understood Carignano, she alone valued that Nanda Kaul knew.” (80) 
So in the conclusion all we can say and realize in all the novels of Anita Desai Nature plays the role of the central theme as all the female protagonists express themselves properly through it. Their inward agony, disturbance and sorrow get its proper expression through Nature and its Natural objects. Nature not only provides them joy and solaces to their agonized and neglected soul but also give their outer world. Nature has the power of nurture and sustenance like the women which we clearly find in all the novels of Anita Desai. We see both the calm and violent side of Nature as we see in case of the agonized and disturbed souls of the female protagonists. So at the end, we can say, all the fictions of Desai warns us to go provide proper affection and respect both to Women and Nature, for the sustenance and peaceful existence of mankind on this green planet. 


\section{References}

Desai, Anita."Replies to the Questionnaire," Kakatiya Journal of English Studies, III-1, 1978.Pp.1-6.

-----. Clear Light of Day. London: William Heinemann, 1980. Print.

---_ery, the Peacock. London: Peter Owen, 1963. New Delhi: Orient, 1990. Print.

Fire on the Mountain. London: William Heinemann, 1977. Print. 